\title{
Erratum to: The impact of statistical learning on violations of the sure-thing principle
}

\author{
Nicky Nicholls ${ }^{1}$ • Aylit Tina Romm ${ }^{2}$. \\ Alexander Zimper ${ }^{1}$
}

Published online: 10 June 2015

(C) Springer Science+Business Media New York 2015

\section{Erratum to: J Risk Uncertain DOI 10.1007/s11166-015-9210-y}

Due to an error during typesetting, the name of author Aylit Tina Romm was incorrect in the original version of this article. The correct authors' list is given above. The original version was corrected. Springer apologizes for the mistake.

The online version of the original article can be found at http://dx.doi.org/10.1007/s11166-015-9210-y.

Alexander Zimper

alexander.zimper@up.ac.za

Nicky Nicholls

nicky.nicholls@gmail.com

Aylit Tina Romm

aylit.romm@wits.ac.za

1 Department of Economics, University of Pretoria, Private Bag X20, Hatfield 0028 Pretoria, South Africa

2 School of Economic and Business Sciences, University of the Witwatersrand, Johannesburg, South Africa 